\title{
Urgensi Perlindungan Hukum Pejabat Daerah Dari Jeratan Tindak Pidana Korupsi
}

\author{
M. Abdim Munib \\ Fakultas Hukum Universitas Bojonegoro \\ Email: nief_advokat@yahoo.com
}

\begin{abstract}
Abstrak
Gencarnya upaya pemberantasan korupsi, terutama di daerah, terkadang dapat mengakibatkan pejabat publik enggan melaksanakan kewajibannya dalam memberikan pelayanan publik dengan dalih khawatir akan terjerat dalam tuduhan tindak pidana. Padahal di sisi lain, dalam penegakan hukum pidana di Indonesia terdapat asas subsideritas. Dengan penerapan asas ini perlindungan hukum kepada setiap pejabat publik di daerah sebenarnya sudah diberikan dengan adanya asas ultimum remedium dalam penegakan hukum pidana, termasuk pidana korupsi, yaitu dengan menjadikan penegakan hukum pidana sebagai alternative pemulihan terakhir setelah penyelesaian bidang hukum perdata maupun hukum administrasi sudah tidak mampu memberikan penyelesaian. Jika prinsip ini dipegang teguh oleh aparat penegak hukum yang berwenang, baik kepolisian, kejaksaan maupun KPK, maka Kepala Daerah akan dengan tenang menunaikan pelayanan publik kepada masyarakat yang membutuhkannya.

Kata Kunci; Perlindungan hukum, korupsi, pemerintah daerah, pelayanan public
\end{abstract}

\section{PENDAHULUAN}

Tujuan penyelenggaraan

pemerintahan negara kesatuan Republik

Indonesia adalah untuk mewujudkan

kesejahteraan rakyat seluruhnya. Segala

kebijakan dan tindakan pemerintahan

harus berlandaskan pada rel tujuan

negara tersebut. Hal ini bukan hanya tanggung jawab eksekutif sebagai pelaksana undang-undang saja, tetapi juga tanggung jawab legislatif, termasuk juga tanggung jawab lembaga yudisial dan perangkat-perangkat penegakan hukum lainnya. Semua elemen negara harus seiring sejalan dalam membuat kebijakan serta menegakkan hukum, dengan mengacu pada tujuan utama penyelenggaraan pemerintahan tersebut, baik di pemerintah pusat maupun pemerintah daerah.

Dalam rangka mewujudkan tujuan negara tersebut, penyelenggaraan pemerintahan yang bersih dan bebas dari perbuatan korupsi, kolusi dan nepotisme (KKN) sudah menjadi komitmen bersama. Ikhtiarnya, dibuatlah peraturanperaturan hukum baru dalam upaya untuk mencegah, menanggulangi dan memberantas tindak pidana yang tergolong extra ordinary crime 
(kejahatan yang luar biasa). Untuk menunjang komitmen tersebut juga didirikan lembaga-lembaga penegak hukum baru seperti Komisi Pemberantasan Korupsi (KPK), atau tidak cukup dengan pembentukan lembaga super body (badan luar biasa) tersebut, yang sedang trend adalah dibentuknya tim sapu bersih pungutan liar (tim saber pungli), yang secara massive dari pusat sampai pelosokpelosok negeri.

Tetapi, upaya pemberantasan tersebut acapkali melenceng dari pakem tujuan penyelenggaraan pemerintahan, yaitu terwujudnya kesejahteraan bagi seluruh rakyat Indonesia. Untuk mewujudkan tujuan negara tersebut seorang pejabat negara membuat kebijakan pemerintahan (diskresi) guna mengatasi kebuntuan hukum atau melakukan inovasi-inovasi kebijakan untuk kemajuan bangsa malah harus berhadapan dengan aparat penegak hukum dengan tuduhan melakukan korupsi. Sungguh ironis, praktek penegakan hukum, terutama dalam pemberantasan korupsi, di negeri yang rentan dengan budaya hukum feodal peninggalan pemerintah kolonial Belanda ini masih dipertahankan.

$$
\begin{array}{ccc}
\multicolumn{2}{c}{\text { Paham-paham legalistik- }} \\
\text { positivistik yang } & \text { cenderung }
\end{array}
$$

mengonsepkan hukum sebagai aturan norma baku, pokoknya hukum harus ditegakkan, walaupun langit runtuh. Bukannya seperti adagium "fiat justicia ruat coelum" (keadilan harus ditegakkan walaupun langit runtuh). Sangat berbeda jauh antara makna adagium tersebut dengan fenomena legisme-positivisme, jika adagium tersebut yang ditegakkan adalah keadilan, sedangkan faham legisme-positivisme yang ditegakkan adalah hukum, lebih parah lagi jika hukum di sini yang dimaksud adalah undang-undang atau hukum tertulis ansich, sehingga mengabaikan hukum yang tidak tertulis dan kepatutan yang hidup dan berkembang dalam kehidupan masyarakat.

Semangat pemberantasan korupsi sekarang ini sangat luar biasa dahsyatnya. Seiring dengan itu pengawasan terhadap penyelenggaraan pemerintahan agar berjalan dengan baik serta selaras dengan prinsip penyelenggaraan pemerintahan yang bersih dan bebas dari KKN begitu luar biasa. Uforia tersebut nampak dengan sangat dominannya berita pemberantasan korupsi di media masa, baik nasional maupun lokal. Terutama berita Kepala Daerah yang terjaring 
operasi tangkap tangan (OTT) oleh KPK. Sebagian besar Kepala Daerah tersebut tertangkap basah sedang menerima uang suap (gratifikasi) sebagai imbalan atas pelayanan publik yang sedang atau telah diberikan.

Akibat upaya pemberantasan korupsi tersebut, terutama di daerah kadang kala pejabat publik abai terhadap kewajibannya dalam memberikan pelayanan publik dengan dalih khawatir akan terjerat dalam tuduhan tindak pidana. Tindak pidana yang biasanya diancamkan adalah tindak pidana korupsi atau tindak pidana umum seperti pemalsuan dan/atau memberikan keterangan palsu yang disertai dengan unsur turut serta melakukan tindak pidana yang diatur dalam Pasal 55 KUHP. Fenomena seperti di daerah tersebut jarang terjadi di pusat karena besarnya komitmen pemerintah pusat untuk memperbaiki pelayanan publik dan pengawasan penyelenggaraan pelayanan publik yang begitu offensive. Sedangkan di daerah, pemerintah derah seringkali berlindung di balik kewenangan tata kelola pemerintahan yang diberikan dalam paket otonomi daerah, sehingga kewajiban untuk memberikan pelayanan publik yang prima kadang terabaikan.

a. Apakah kebijakan pejabat publik dalam rangka menyelenggarakan pelayanan publik di daerah dapat dipidanakan?

b. Perlukah perlindungan hukum bagi pejabat daerah agar tidak khawatir terhadap ancaman tindak pidana korupsi dalam menyelenggarakan pelayanan publik?

\section{METODE PENELITIAN}

Menurut Peter Mahmud, "Penelitian hukum adalah suatu proses untuk menemukan aturan hukum, prinsip-prinsip hukum, maupun doktrindoktrin hukum guna menjawab isu hukum yang dihadapi". ${ }^{1}$ Metode penelitian hukum adalah sebagai cara kerja ilmuan yang salah satunya ditandai dengan penggunaan metode. Secara harfiah mula-mula metode diartikan sebagai suatu jalan yang harus ditempuh menjadi penyelidikan atau penelitian berlangsung menurut suatu rencana tertentu. $^{2}$ Metode penelitian hukum merupakan suatu cara yang sistematis dalam melakukan sebuah penelitian.

1 Peter Mahmud Marzuki,Penelitian Hukum, Kencana Prenada Media Group, Jakarta, 2011, h.35

${ }^{2}$ Ibid. h. 171. 
Melalui penelitian yuridis normatif dengan pertimbangan bahwa titik tolak penelitian analisis terhadap peraturan perundang-undangan dalam kerangka hukum nasional Indonesia sendiri. Maka tipe penelitian yang digunakan adalah penelitian juridis normatif, yakni penelitian yang difokuskan untuk mengkaji penerapan kaidah kaidah atau norma-norma dalam hukum positif, ${ }^{3}$ Pendekatan perundang-undangan (statute approach) dilakukan untuk meneliti dan mengalisis undang-undang dan pengaturan yang bersangkut paut dengan Peran Hukum Administrasi Negara dalam Penanggulangan Tindak Pidana Pemilu. Pendekatan konsep (conceptual approach), digunakan untuk mempelajari pandangan dan doktrin yang berkembang di dalam ilmu hukum. ${ }^{4}$

\section{PEMBAHASAN}

\section{Kebijakan Pejabat Publik Dalam} Rangka Menyelenggarakan Pelayanan Publik Di Daerah Tidak Dapat Dipidanakan

Fenomena cukup banyaknya Pejabat Publik di daerah harus berurusan dengan penegak hukum akibat sangkaan

\footnotetext{
${ }^{3}$ Ibid.,

${ }^{4}$ Ibid., h. 24
}

tindak pidana korupsi, memerlukan perhatian khusus agar kehidupan berbangsa dan beernegara tetap istiqamah pada tujuan negara, yaitu untuk menciptakan kesejahteraan rakyat. Dalam menjalankan tugas, fungsi dan wewenangnya sebagai penyelenggara pelayanan publik kadang berbenturan dengan permasalahan antara aspek hukum pidana yang memiliki korelasi dengan fungsi administrasi. Meski kadangkala pemaknaan area hukum pidana tidak terlepas terhadap persoalan implementasi fungsi tersebut, akibatnya tidak jarang pejabat publik di daerah mengalami keraguan dalam menjalankan fungsi dan wewenangnya, khususnya dalam menjalankan wewenangnya yang dapat dipersepsikan oleh penegak hukum sebagai kebijakan yang koruptif atau perbuatan koruptif yang berlindung di balik kebijakan.

Sehubungan dengan fenomena ancaman kriminalisasi kebijakan ini Marwan Effendi berpendapat bahwa:

Jika setiap kebijakan dapat dikualifikasi sebagai tindak pidana korupsi, tentu akan dilematis. Padahal diketahui, bahwa kebijakan tersebut adalah bagian dari suatu sistem, jika seorang pejabat pemerintah takut mengambil suatu kebijakan, maka roda pemerintahan tidak akan berjalan sebagaimana yang diharapkan. Lebih- 
lebih jika kegiatan tersebut terkait dengan bisnis, maka akan berdampak terhadap investasi kalau khawatir kebijakan tersebut terjerat pidana. ${ }^{5}$

Jika tindak pidana yang dipersangkakan adalah tindak pidana korupsi, merupakan isu yang sensitif dan menakutkan bagi pejabat publik. Apalagi jika perbuatan tersebut terpublikasi melalui derasnya pemberitaan media, sang pejabat akan mengalami trauma yang lebih kronis lagi. Mereka sadar ini adalah era demokrasi, betapa kuatnya pengaruh media informasi dalam kehidupan berbangsa. Bahkan nasibnya ke depan juga dipengaruhi oleh publisitas media di tengah masyarakat pemilihnya.

Di sisi lain, Undang-Undang Nomor 31 Tahun 1999 tentang Pemberantasan Tindak Pidana Korupsi yang telah diubah dengan UndangUndang Nomor 20 Tahun 2001 tentang Perubahan Atas Undang-Undang Nomor 31 Tahun 1999 tentang Pemberantasan Tindak Pidana Korupsi mendefinisikan korupsi sebagai perbuatan memperkaya

\footnotetext{
${ }^{5}$ Marwan Effendy, 2010, Apakah Suatu Kebijakan Dapat Di Kriminalisasi? (Dari Perspektif Hukum Pidana/Korupsi), Makalah disampaikan dalam Seminar, dengan tema "Pertanggungjawaban Kebijakan Ditinjau Dari Hukum". yang diselenggarakan oleh Lembaga Pengembangan Fraud Auditing (LPFA) $11 \mathrm{Mei}$ 2010, h. 22;
}

diri sendiri atau orang lain atau suatu korporasi yang dapat merugikan keuangan negara atau perekonomian negara.

Ketentuan normatif tersebut dapat menimbulkan multi tafsir terhadap tindakan pemerintahan (diskresi) yang dilakukan pejabat publik. Sebab, walaupun tidak mengambil keuntungan pribadi, bila suatu kebijakan atau tindakan menguntungkan orang lain dan merugikan keuangan negara, seorang pejabat dapat diancam dengan tindak pidana korupsi. Bahkan, memotong prosedur untuk kepentingan publik dapat dianggap suatu pelanggaran. Hal ini menjadi jebakan bagi pejabat publik yang melakukan diskresi ketika menghadapi masalah yang harus direspon secara cepat. Akibatnya, timbul ketakutan untuk mengambil keputusan atas persoalan yang mendesak dan harus segera diselesaikan. Sebab, di kemudian hari mereka dapat dipermasalahkan dan dituduh melakukan tindak pidana korupsi.

Padahal dalam praktek penegakan hukum menurut Indriyanto Seno Adji, setelah menganalisis pendapat dari Lie On Hock berpendapat bahwa: "Seorang hakim yang menangani suatu pekara 
pidana biasa tidak diperkenankan mengadili mengenai kebijakan biasa dan menurutnya bukan pengadilan yang dapat menilai kebijakan, karena kebijakan tersebut merupakan freies ermessen, sehingga tidak boleh dicampuri oleh Hakim umum". 6

Selaras dengan pendapat tersebut, Andi Wahyudi juga menegaskan bahwa:

Suatu kebijakan, karena sifatnya yang dilakukan dalam kondisi mendesak dan keterbatasan kekuasaan, berpotensi menerabas prosedur formal yang telah ditetapkan. Dalam kondisi normal, prosedur formal memang harus diikuti. Tetapi, dalam kondisi yang tidak normal untuk mengatasi persoalan yang konkret, prosedur formal sementara dapat dikesampingkan dengan alasan yang rasional. ${ }^{7}$

Sebaiknya dalam penegakan hukum korupsi ini kita harus belajar dari Negara lain. Sebagai perbandingan pemberantasan korupsi di Selandia Baru, negara yang terkenal paling bersih dari korupsi, justru tidak memiliki definisi korupsi secara khusus. Serious Fraud Office (SFO), lembaga pemberantasan korupsi di negara tersebut, menggunakan

${ }^{6}$ Indriyanto Seno Adji, 2009, Korupsi dan Penegakan Hukum, Jakarta; Diadit Media, h. 27;

7 Andi Wahyudi, 2015, Dahlan Iskan, Diskresi dan Jebakan Hukum, Opini Harian Pagi Jawa Pos, edisi 09 Juni 2015; definisi korupsi dari Asian Development

Bank $(A D B)$, yaitu:

Behaviour on the part of officials in the public or private sector in which they improperly and unlawfully enrich themselves or those close to them, or induce others to do so, by misusing the position in which they are placed". (Perbuatan pejabat publik atau swasta yang secara tidak benar dan tidak sah memperkaya diri atau orang dekatnya atau membujuk orang lain untuk melakukannya dengan menyalahgunakan posisi jabatannya).

Dengan definisi ini, di negara tersebut bukan hanya sektor pemerintah, sektor swasta pun dapat menjadi yuridiksi lembaga anti korupsi dan peradilan tindak pidana korupsi, jika ada unsur penyalahgunaan kewenangan.

Memang tidak mudah menentukan suatu parameter kebijakan dari perspektif hukum, mengingat kebijakan dapat dilihat dari berbagai sudut pandang, baik itu hukum administrasi, hukum perdata maupun hukum pidana. Di sini perlunya membedakan kebijakan tersebut dari sudut pandang hukum administrasi dan hukum perdata serta hukum pidana, sehingga dapat dihindari adanya kesan terjadi kriminalisasi terhadap suatu kebijakan. Hal ini yang menjadi salah satu sebab para pejabat 
penyelenggara pelayanan publik terkadang enggan memberikan pelayanan publik yang sudah menjadi kewajiban jabatannya.

Dalam perkembangan pengertian kebijakan, baik dari perspektif hukum administrasi, hukum perdata maupun hukum pidana adalah merupakan pengertian yang berada di wilayah abuabu parameter kebijakan tersebut dari berbagai perspektif hukum, meskipun dengan segala teknikalitas akan mengalami kesulitan, tidak terkecuali menyangkut pemidanaan. Oleh karena itu menurut Indriyanto Seno Adji, menyatakan bahwa:

Karena di kalangan para ahli hukum pidana hingga saat ini masih menjadi debatalitas. Oleh karena itu keputusan pejabat negara baik dalam rangka beleid (vrijbestuur) maupun diskresi (kebijaksanaan-discretionary power) maupun kerangka privaatrechtelijke hingga saat ini masih menjadi ajang kajian akademis, baik menyangkut alasan penolakan maupun justifikasi pemidanaan. $^{8}$

Dari perspektif hukum administrasi yang menjadi parameter untuk membatasi gerak bebas kewenangan aparatur negara (discretionary power) adalah dengan instrumen indikasi adanya perbuatan

\footnotetext{
${ }^{8}$ Indriyanto Seno Adji, 2009, Op.cit, h.
}

penyalahgunaan

wewenang

(detournement de pouvoir) dan sewenang-wenang (abus de droit). Sedangkan dalam hukum pidana kriteria yang membatasi gerak bebas kewenangan aparatur negara disebut sebagai unsur melawan hukum (wederechtelikheid) dan unsur menyalahgunakan wewenang. Begitu juga dalam hukum perdata perbuatan melawan hukum tersebut disebut sebagai onrechtmatigedaad dan/atau wanprestasi. Pengertian terakhir ini seringkali dipahami secara menyimpang oleh penegak hukum karena menganggap pengertian luas dari onrechtmatigedaad dalam hukum perdata mempunyai pengertian yang sama dengan pengertian hukum pidana terhadap istilah materiels wederrechtelijkheid.

Indriyanto Seno Adji, berpendapat bahwa:

Istilah wederrechteljkheid dalam beberapa kepustakaan kadangkala diartikan dengan istilah lain, seperti "tanpa hak sendiri", "bertentangan dengan hukum pada umumnya", "bertentangan hak pribadi seseorang", "bertentangan dengan hukum positif' (termasuk hukum perdata, hukum administrasi) atau pun 1. 
"menyalahgunakan wewenang" dan lain sebagainya. ${ }^{9}$

Pola penyelesaian terhadap penyimpangan dalam penyalahgunaan wewenang adalah melalui peradilan administrasi atau melalui mekanisme alternatif penyelesaian sengketa di Ombudsman. Akhir-akhir ini berkembang juga pandangan yang menyatakan apabila seorang pejabat yang mengeluarkan suatu kebijakan yang sebenarnya tidak dapat dinilai oleh hakim pada pengadilan pidana. Pandangan Van Bemmelen merupakan kutipan dari pendapat dari Von Feuerbach yang menyatakan:

1) Setiap penggunaan pidana hanya dapat dilakukan berdasarkan hukum pidana (nulla poena sine lege).

2) Penggunaan pidana hanya mungkin dilakukan jika terjadi perbuatan yang diancam pidana oleh undangundang (nulla poena sine crimine).

3) Perbuatan yang diancam dengan pidana menurut undang-undang membawa akibat hukum bahwa pidana yang diancamkan oleh undang-undang yang

${ }^{9}$ Indriyanto Seno Adji, 2009, Korupsi, Kebijakan Aparatur Negara dan Hukum Pidana, Jakarta; Diadit Media, cet. Ketiga, h. 131-132; diancamkan (nullum crimen sine poena legali). ${ }^{10}$

Mengacu kepada asas legalitas, sepertinya tidak mungkin ada suatu kebijakan dapat dijatuhi pidana, mengingat kebijakan tersebut adalah merupakan perbuatan yang melaksanakan tugas-tugas pemerintahan yang dilakukan berdasarkan kewenangan yang dimilikinya. Lain halnya, jika kebijakan tersebut telah masuk ke dalam rumusan delik dan memenuhi unsurunsurnya, maka perbuatan tersebut dapat dipidana. Selanjutnya menurut J.M. Bemmelen terkait syarat pemidanaan harus memenuhi kriteria adanya: "actus reus berupa kesalahan (schuld), melawan hukum (wederrechtelijke) dan mens rea berupa perbuatan tersebut dapat dipertanggungjawabkan secara pidana". ${ }^{11}$

Dalam sistem hukum anglosaxon, syarat pemidanaan itu harus memenuhi syarat ada asas actus reus dan mens rea, sehingga dalam pemidanaan yang harus digunakan adalah unsur melawan hukum formal, artinya ada atau tidak dalam perbuatan tersebut hal-hal yang bertentangan dengan hukum positif

10 J.M. Bemmelen, 1987, Hukum Pidana 1, Jakarta; Bina Cipta, Cetakan Kedua, h. 49;

11 Ibid., h. 51-52; 
tertulis mengingat alasan yang primaritas sifatnya dari asas nullum delictum sine previa lege punale (suatu perbuatan tidak dapat dipidana jika tidak ada peraturan perundang-undangan yang mengaturnya), yang tercantum pada Pasal 1 ayat 1 KUHP. Sebagai contoh dalam unsur melawan hukum tidak ditemukan secara eksplisit karena dengan adanya kalimat menyalahgunakan kewenangan sudah tersirat unsur melawan hukum tersebut, lagi pula tidak akan ditemukan delik menyalahgunakan kewenangan yang dilakukan secara kealpaan (culpa) yang ada keterkaitan antara schuld (kesalahan) dengan wederrechtelijk (melawan hukum) adalah sangat menentukan pemidanaan, tetapi mungkin saja ada wederrechtelijke (melawan hukum) tanpa adanya schuld (kesalahan). Indriyanto Seno Adji menyampaikan bahwa pemidanaan atas dasar positive materiels wederrechtelijk harus memperhatikan permasalahanpermasalahan sensitif dalam hukum pidana yaitu:

1. Apabila perbuatan pelaku (Terdakwa) secara formil tidak terdapat wederrechtelijke (tidak ada penyalahgunaan wewenang) maka seharusnya yang bersangkutan harus dibebaskan dari segala tuduhan yang berarti terhadap pelaku tidak dapat dikenakan pemidanaan dengan suatu pendekatan analogi.

2. Harus ditentukan kriteria yang menentukan alasan-alasan yang mendasari diimplementasikannya ajaran melawan hukum dalam fungsi positif dalam kaitannya dengan unsur menyalahgunakan wewenang antara lain: Perbuatan pelaku yang tidak termasuk atau tidak memenuhi rumusan delik, dipandang dari kepentingan hukum, ternyata menimbulkan kerugian yang jauh tidak seimbang bagi masyarakat atau negara, dibandingkan dengan keuntungan yang disebabkan oleh perbuatannya yang tidak tidak melanggar peraturan perundang-undangan. Menimbulkan kerugian yang jauh tidak seimbang bagi masyarakat/negara adalah bahwa apabila seorang pegawai negeri atau penyelenggara negara, meskipun tidak melakukan pelanggaran peraturan yang ada sanksi pidananya (formiele tidak wederrechtelik), tetapi menerima fasilitas yang berlebihan serta keuntungan lainnya dari seseorang/korporasi/badan hukum dengan maksud agar pegawai negeri atau penyelenggara negara itu menggunakan kekuasaan atau wewenang yang melekat pada jabatannya secara berlebihan atau menyimpang. ${ }^{12}$

Berdasarkan syarat-syarat pemidanaan baik actus reus dan mens rea, asas-asas pemerintahan yang baik maupun pertanggungjawaban pidana, maka

${ }^{12}$ Indriyanto Seno Adji, 2009, Op. Cit., h. 16-17; 
bukan membuat suatu kebijakan yang dapat dipidana, tetapi adalah pejabat yang membuat kebijakan tersebut, jika dalam menetapkan kebijakan tersebut mengandung unsur penyalahgunaan wewenang atau di balik suatu kebijakan yang ditetapkannya itu pejabat tersebut memperoleh keuntungan untuk diri sendiri atau orang lain dan dapat menimbulkan kerugian negara. Untuk itu, maka seorang pejabat yang mengeluarkan suatu kebijakan tidak dapat diminta pertanggungjawaban pidananya, apabila dalam mengambil atau menetapkan kebijakan tersebut tidak ada suatu maksud atau niat kesengajaan untuk melakukan penyalahgunaan wewenang dan dirinya memperoleh keuntungan atau menguntungkan orang lain dan telah menimbulkan kerugian negara.

Penyalahgunaan wewenang itu dapat saja dilakukan karena pejabat pembuat kebijakan tersebut berbuat curang, tidak adil, menyembunyikan sesuatu atau adanya unsur korupsi yang dilakukan pejabat tersebut mendapat gratifikasi atau hadiah atau bentuk keuntungan materi lainnya, baik langsung maupun secara tidak langsung atas kebijakan yang telah diambilnya.

Untuk memilah parameter abu-abu antara persepsi hukum pidana dan hukum administrasi tersebut, Marwan Effendy, berpendapat bahwa:

Agar tidak terjadi tumpang tindih (overlapping) pengaturan, seperti halnya penerapan Undang-Undang Tindak Pidana Korupsi terhadap administrative penal law, yang seharusnya hanya dapat dijerat dengan undang-undang pokoknya sendiri, karena dilihatnya sudah mengatur tentang sanksi pidana terhadap pelanggarnya seperti pembalakan liar (illegal logging), perikanan, pajak, kepabeanan, lingkungan hidup di samping undangundang dimaksud sudah mengatur sendiri tentang pengembalian kerugian negara. Hal tersebut berbeda dengan masalah yang terkait dengan perbankan meskipun sebagai administrative penal law, tetapi undang-undang tidak mengatur sendiri, karena tidak mengatur sendiri tentang pengembalian kerugian negaranya. ${ }^{13}$

Pembahasan mengenai kebijakan dalam konteks ini tidak dapat dilepaskan dari asas-asas umum pemerintahan yang baik (algemene beginselen van behoorlek bestuur). Yang menurut ketentuan Pasal 10 ayat (1) UndangUndang Nomor 30 Tahun 2014 tentang Administrasi Pemerintahan menentukan bahwa:

\footnotetext{
${ }^{13}$ Effendi, 2010, Op. Cit., h. 29;
} 
AUPB yang dimaksud dalam undang-undang ini meliputi asas:
a. kepastian hukum.

b. kemanfaatan.

c. ketidakberpihakan.

d. kecermatan.

e. tidak menyalahgunakan kewenangan.

f. keterbukaan.

g. kepentingan umum, dan

h. pelayanan yang baik.

Di antara asas-asas ini yang lebih disoroti adalah asas tidak menyalahgunakan kewenangan, dalam asas ini kewajiban seorang administrator atau pejabat untuk mengusahakan agar suatu kebijakan menuju sasaran yang tepat. Suatu kebijakan tidak boleh ditujukan pada hal-hal lain dari sasaran atau tujuan semula kalau hal ini terjadi maka telah terjadi penyalahgunaan wewenang sehingga menimbulkan penyalahgunaan wewenang (detournement de pouvoir) yang dapat mengakibatkan batalnya kebijakan tersebut. Karena adanya larangan di dalam menetapkan suatu kebijakan membonceng tujuan-tujuan yang bermaksud mencari keuntungan bagi diri sendiri baik langsung maupun secara tidak langsung.

\section{Perlindungan Hukum Bagi} Pejabat Daerah Terhadap Ancaman Tindak Pidana Korupsi
Dalam

Menyelenggarakan

\section{Pelayanan Publik}

Upaya pemberantasan tindak pidana korupsi, termasuk juga yang dilakukan di daerah, baik oleh KPK, Kepolisian maupun Kejaksaan sebenarnya tidak semuanya terkait langsung dengan penyelenggaraan pelayanan publik oleh pemerintah daerah. Hanya terkadang wewenang untuk memberikan pelayanan publik tertentu seringkali disalahgunakan oleh Kepala Daerah, misalnya dengan meminta sejumlah uang gratifikasi, atau malah tidak meminta tapi sudah disediakan oleh pihak tertentu sebagai imbalan jasa atas pelayanan bagus yang telah diberikan. Tetapi dalam praktek, dimungkinkan pejabat publik tertentu tidak berkenan memberikan pelayanan publik yang sudah menjadi kewajibannya dengan alasan khawatir akan ancaman pidana korupsi jika pelayanan tersebut diberikan. Dari landasan pemikiran ini muncul gagasan perlunya perlindungan hukum bagi pejabat publik dalam mengambil kebijakan pemerintahan.

Perlindungan hukum bagi pejabat publik sebenarnya telah diatur dalam 
peraturan perundang-undangan yang

berlaku di Indonesia, di antaranya:

1) Undang-Undang Nomor 8 Tahun 1981 tentang Hukum Acara Pidana Dalam konsideran Undang-Undang Nomor 8 Tahun 1981 tentang Hukum Acara Pidana, khususnya dalam bab menimbang huruf a dinyatakan bahwa:

"Negara Republik Indonesia adalah negara hukum berdasarkan Pancasila dan Undang-Undang Dasar 1945 yang menjunjung tinggi hak asasi manusia serta yang menjamin segala warga negara bersamaan kedudukannya di dalam hukum dan pemerintahan dan wajib menjunjung hukum dan pemerintahan itu dengan tidak ada kecualinya. "“

Pernyataan pernyataan

penjaminan di hadapan hukum dan pemerintahan tersebut diberikan kepada semua Warga Negara, termasuk di dalamnya aparatur negara. Artinya Negara melindungi hak atas kehidupan pribadi setiap aparatur negara sehingga aparat penegak hukum tidak dapat berlaku semena-mena (corrupt), walaupun telah diduga pejabat publik tersebut diindikasikan berbuat tindak pidana korupsi. Namun sangat disayangkan pengaturan norma tersebut hanya pada konsideran, tidak dijabarkan lebih lanjut dalam batang tubuh. Pengaturan demikian memberikan konsekuensi hanya sekedar sikap kehatihatian bagi penegak hukum saja. Lain halnya jika diatur dalam batang tubuh yang tentunya mempunyai daya ikat prosedural yang menimbulkan akibat hukum terhadap suatu produk hukum jika dilanggar. Apalagi jika diatur prosedur yang jelas dan diberikan juga akibat hukum, misalnya adanya cacat hukum jika prosedur itu dilanggar, maka pengaturan perlindungan hukum tersebut lebih implementatif dalam praktek

2) Undang-Undang Nomor 28 Tahun 2007 Tentang Perubahan Ketiga Atas Undang-Undang Nomor 6 Tahun 1983 Tentang Ketentuan Umum Dan Tata Cara Perpajakan

Ketentuan norma yang terkandung dalam Pasal 36A ayat (5) Undang-Undang KUP Tahun 2007 mengatur bahwa: "Pegawai pajak tidak dapat dituntut, baik secara perdata maupun pidana, apabila dalam melaksanakan tugasnya didasarkan pada i'tikad baik dan sesuai dengan ketentuan peraturan perundang-undangan perpajakan”. Penjelasan Pasal 36A ayat (5) menyatakan bahwa: "Pegawai pajak dalam melaksanakan tugasnya dianggap 
berdasarkan i'tikad baik apabila pegawai pajak tersebut dalam melaksanakan tugasnya tidak untuk mencari keuntungan bagi diri sendiri, keluarga, kelompok, dan/atau tindakan lain yang berindikasi korupsi, kolusi, dan/atau nepotisme". Tentunya Undang-Undang ini tidak hanya mengikat petugas pajak di kementerian keuangan saja, tetapi juga mengikat pada petugas di daerah, dengan segala wewenang yang dimilikinya.

3) Undang-Undang Republik Indonesia Nomor 30 Tahun 2014 tentang

Administrasi Pemerintahan

Menurut ketentuan Pasal 6

Undang-Undang Republik Indonesia Nomor 30 Tahun 2014 tentang Administrasi Pemerintahan yang menentukan bahwa:

(1) Pejabat Pemerintahan memiliki hak untuk menggunakan kewenangan dalam mengambil keputusan dan/atau tindakan.

(2) Hak sebagaimana dimaksud pada ayat (1) meliputi:

a. Melaksanakan Kewenangan yang dimiliki berdasarkan ketentuan peraturan perundang-undangan dan AUPB;

b. Menyelenggarakan pemerintahan aktivitas Kewenangan yang dimiliki; c. Menetapkan keputusan berbentuk tertulis atau elektronis dan/atau menetapkan tindakan;

d. Menerbitkan atau tidak menerbitkan, mengubah, mengganti, mencabut, menunda, dan/atau membatalkan keputusan dan/atau tindakan;

e. Menggunakan diskresi sesuai dengan tujuannya;

f. Mendelegasikan dan memberikan mandat kepada pejabat pemerintahan lainnya sesuai dengan ketentuan peraturan perundang-undangan;

g. Menunjuk pelaksana harian atau pelaksana tugas untuk melaksanakan tugas apabila pejabat definitif berhalangan;

h. Menerbitkan Izin, dispensasi, dan/atau konsesi sesuai dengan ketentuan peraturan perundangundangan;

i. Memperoleh perlindungan hukum dan jaminan keamanan dalam menjalankan tugasnya;

j. Memperoleh bantuan hukum dalam pelaksanaan tugasnya;

k. Menyelesaikan sengketa kewenangan di lingkungan atau wilayah kewenangannya;

1. Menyelesaikan upaya administratif yang diajukan masyarakat atas keputusan dan/atau tindakan yang dibuatnya; dan

m. Menjatuhkan sanksi administratif kepada bawahan yang melakukan pelanggaran sebagaimana diatur dalam Undang-Undang ini.

Dalam norma hukum tersebut sudah terdapat kepastian bahwa setiap pejabat publik yang sedang menjalankan roda pemerintahan berhak menadapatkan perlindungan hukum atas kebijakan atau keputusan administratif yang telah 
diambilnya. Beberapa ketentuan hukum yang berbeda era penetapannya tersebut, tentunya juga mempunyai filosofi dan politik hukum yang berbeda, terutama dalam menjalankan amanat pemberantasan tindak pidana korupsi. Namun kenyataannya secara substansial terdapat keseragaman kehendak politik hukum bahwa untuk melindungi kepentingan yang lebih besar yaitu terwujudnya kesejahteraan bangsa, terutama dengan upaya yang utama yaitu penyelenggaraan pelayanan publik, maka beberapa ketentuan normatif tersebut sepakat untuk memberikan wewenang yang luas dalam penyelenggaraan pelayanan publik, membuat terobosan kebijakan dan inovasi-inovasi dalam penyelenggaraan pemerintahan.

Di samping norma hukum yang dipaparkan di atas, yang lebih patut diperhatikan adalah berlakunya asas subsideritas dalam penegakan hukum pidana. Dalam asas subsideritas ini penegakan hukum pidana hanya dilakukan sebagai upaya penegakan hukum yang terakhir (ultimum remedium), setelah terlebih dahulu diupayakan penegakan hukum perdata dan hukum administrasi menemui jalan buntu (deadlock), sehingga kerugian Negara menjadi suatu yang nyata yang harus dikembalikan, terutama karena tidak adanya i'tikad baik untuk menyelesaikan permasalahan tersebut. Sebuah asas adalah ruh bagi ilmu hukum, jika asas ini diabaikan, maka tidak ada lagi karakter ilmu hukum sebagai ilmu yang murni dan mandiri, yang bebas dari pengaruh kekuasaan.

Dengan demikian, penegakan hukum pidana merupakan upaya hukum terakhir, jika penegakan hukum administrasi, perdata dan alternatif penyelesaian lainnya dinilai belum dapat menyelesaikan masalah. Namun demikian ketentuan tersebut dapat dikesampingkan apabila tingkat kesalahan pelaku relatif berat, perbuatannya relatif besar, atau perbuatannya menimbulkan keresahan masyarakat.

\section{KESIMPULAN}

a. Berdasarkan syarat-syarat pemidanaan baik actus reus dan mens rea, asas-asas pemerintahan yang baik maupun pertanggungjawaban pidana, maka bukan membuat suatu kebijakan yang dapat dipidana, tetapi adalah pejabat yang 
membuat kebijakan tersebut, jika dalam menetapkan kebijakan tersebut mengandung unsur penyalahgunaan wewenang atau di balik suatu kebijakan yang ditetapkannya itu pejabat tersebut memperoleh keuntungan untuk diri sendiri atau orang lain dan dapat menimbulkan kerugian negara. Untuk itu maka seorang pejabat yang mengeluarkan suatu kebijakan tidak dapat diminta pertanggungjawaban pidananya, apabila dalam mengambil atau menetapkan kebijakan tersebut tidak ada suatu maksud atau niat kesengajaan untuk melakukan penyalahgunaan wewenang dan dirinya memperoleh keuntungan atau menguntungkan orang lain dan telah menimbulkan kerugian negara.

b. Perlindungan hukum kepada setiap pejabat publik di daerah sebenarnya sudah diberikan dengan adanya asas subsideritas berupa tindakan ultimum remedium (pemulihan terakhir) dalam penegakan hukum pidana, termasuk pidana korupsi, yaitu dengan menjadikan penegakan hukum pidana sebagai alternative pemulihan terakhir setelah penyelesaian bidang hukum perdata maupun hukum administrasi sudah tidak mampu memberikan penyelesaian. Jika prinsip ini dipegang teguh oleh aparat penegak hukum yang berwenang, baik kepolisian, kejaksaan maupun KPK, maka Kepala Daerah akan dengan tenang menunaikan pelayanan publik kepada masyarakat yang membutuhkannya.

Rekomendasi yang dapat diberikan adalah sebagai berikut;

a. Kepada penegak hukum agar lebih memperhatikan keadilan yang terkandung dalam hukum daripada hukumnya sendiri, terutama asas-asas hukum, termasuk asas subsideritas harus benar-benar ditegakkan agar hukum mempunyai karakter yang melekat pada tujuan bangsa, yaitu mewujudkan kesejahteraan rakyat.

b. Kepada pejabat daerah agar lebih istiqamah lagi dalam memberikan pelayanan publik di daerah. Karena terhadap 
penyelenggara pelayanan publik baik di pusat maupun daerah sudah mendapatkan perlindungan hukum, asalkan kebijakan yang diambil tidak dimaksudkan untuk menutupi perbuatan koruptif yang berlindung di balik kebijakan.

\section{DAFTAR PUSTAKA}

\section{Buku}

Adji, Indriyanto Seno, 2009, Korupsi dan Penegakan Hukum, Jakarta; Diadit Media;

-----------, 2009, Korupsi, Kebijakan Aparatur Negara dan Hukum Pidana, Jakarta; Diadit Media, cet. Ketiga;

Asshiddiqie, Jimly, 2015, Paradigma Baru Pembangunan Daerah, Makalah disampaikan dalam kegiatan Ceramah dalam forum yang diselenggarakan oleh Pemda Provinsi Kalimantan Timur di Samarinda, 23 Maret, 2015;

Bemmelen, J.M., 1987, Hukum Pidana 1, Jakarta; Bina Cipta,Cetakan Kedua;

Cheema, G. Shabbir dan Dennis A. Rondinelli, 2007, From Government Decentralization to Decentralized Governance, Washington, DC; The Brookings Institution:

Effendy, Marwan, 2010, Apakah Suatu Kebijakan Dapat Di Kriminalisasi? (Dari Perspektif Hukum Pidana/Korupsi), Makalah disampaikan dalam Seminar, dengan tema "Pertanggungjawaban Kebijakan Ditinjau Dari Hukum". yang diselenggarakan oleh
Lembaga Pengembangan Fraud Auditing (LPFA). di Hotel Bumi Karsa Bidakara - Jakarta, Selasa 11 Mei 2010;

Hadjon, Phillipus M., 1987, Perlindungan Hukum Bagi Rakyat Indonesia, Surabaya: Bina Ilmu;

Mertokusumo, Sudikno, 2008, Mengenal Hukum; Suatu Pengantar, Yogyakarta; Liberty, cetakan keempat;

Mertokusumo, Sudikno, 2009. Penemuan Hukum, Bandung; Citra Aditya Bakti;

Raharjo, Satjipto, 2012, Ilmu Hukum, Bandung; Citra Aditya Bakti;

Tim Penyusun, 2006, Desentralisasi 2006; Membedah Reformasi Desentralisasi di Indonesia, Ringkasan Laporan, Jakarta; USAID Democratic Reform Support Program (DRSP) Untuk Donor Working Group on Decentralization;

\section{Undang-undang}

Undang-Undang Nomor 8 Tahun 1981 tentang Hukum Acara Pidana

Undang-Undang Nomor 20 Tahun 2001 tentang Perubahan Atas UndangUndang Nomor 31 Tahun 1999 Tentang Pemberantasan Tindak Pidana Korupsi

Undang-Undang Nomor 32 Tahun 2004 tentang Pemerintahan Daerah

Undang-Undang Nomor 28 Tahun 2007 Tentang Perubahan Ketiga Atas Undang-Undang Nomor 6 Tahun 1983 Tentang Ketentuan Umum Dan Tata Cara Perpajakan Undang-Undang Nomor 30 Tahun 2014 tentang Administrasi Pemerintahan

Undang-Undang Nomor 9 Tahun 2015 tentang Perubahan Atas UndangUndang Nomor 23 Tahun 2014 tentang Pemerintahan Daerah 